\title{
RAPID ASSESSMENT OF PROTECTED AREA PRESSURES AND THREATS IN NIGERIA NATIONAL PARKS
}

\author{
A. A. NCHOR AND A. U. OGOGO
}

(Received 23 May 2012; Revision Accepted 29 June 2012)

\section{ABSTRACT}

Regular evaluation of protected area operations can enable policy makers develop strategic responses to pervasive management problems. Pressures and threats in seven National Parks of the National Park Service (NPS) were therefore assessed using the Rapid Assessment and Prioritization of Protected Area Management (RAPPAM) methodology. The parks were Cross River National Park (CRNP), Okomu National Park (ONP), Old Oyo National Park (OONP), Gashaka -Gumti National Park (GGNP), Kainji Lake National Park (KLNP), Chad Basin National Park (CBNP) and Kamuku National Park (KNP). Quantitative data was collected from 207 rangers and 49 senior staff including park records. Data were analyzed using descriptive statistics and Spearman correlation. The parks had professionals (1.06\%), technical staff $33(2.19 \%)$, rangers $1094(72.55 \%)$, and administrative staff $266(17.64 \%)$. Personnel cost (19.6\%), administrative operations (36.9\%) and conservation of park resources (3.4\%) were significantly $(p<0.05)$ different. The greatest threats facing the parks were Grazing $(57.76 \%)$, Hunting $(24.17 \%)$, Logging $(6.17 \%)$ and Fishing $(5.06 \%)$. Threats and pressures were positively and significantly correlated $(r=0.75$, $\mathrm{P}<0.05)$ with vulnerability. The staff profile and inappropriate budgetary allocation to conservation activities might be responsible for the overall pressures and threats recorded in the parks during the study.

KEYWORDS: Threats, Pressures, Protected Areas, National Park, Management

\section{INTRODUTION}

Recent decades have recorded serious global biodiversity decline due to loss of species, habitat and major alterations of ecosystems. This has given rise to profound species extinction crises (Heywood 1995, Primm et al 1995, Whitemore 1997). Consequently, much of tropical biodiversity is unlikely to survive without effective protection (Primm et al 1995, Meyers et al 2000). To address these problems, protected areas of various categories have been established across the country. Some studies have further demonstrated that protected areas can be a basic mechanism likely to guide against unsustainable utilization of natural resources. However, these areas most often appear to lack adequate manpower to address a host of myriad and threats within their borders (Brunner et al 2001, Putz et al 2001, Ervin 2003 a, b). Consequently, increasing levels of environmental degradation are now common features in protected areas all over the world. Out of 201 National Parks surveyed in 16 tropical countries, $70 \%$ are being affected by poaching, encroachment and logging (Van Schaik et al 1997). Consequently, a major environmental concern of conservation practitioners all over the world is to improve and optimize management strategies that will assess the threat status of protected areas and measure the management effectiveness of their conservation efforts (Margolis and Salafsky 1999, Hockings et al
2000, Salafsky et al 2002). These assessments are seriously considered as integral components of systematic conservation planning processes (Margules and Pressey 2000).

A number of studies have also examined the level of exploitation of Nigeria's natural resources. Poaching of wildlife resources constitutes the greatest problem to conservation of wildlife in the National Parks and Game Reserves (Alarape, 2002). Though the country has shown increasing concern over the preservation of her indigenous resources in the past, the goals of managing its wildlife resources sustainably has remained unrealized. The major problems of managing wildlife in Nigeria are loss of wildlife habitats, poaching including overhunting, collection of NTFP'S, logging and grazing. This study therefore assessed the level of pressures and threats in the seven National Parks that are presently under the Nigeria National Park Service.

\section{MATERIALS AND METHODS}

Study Area: The assessment covered the seven National Parks presently under the NPS with the following areas: ONP $\left(197 \mathrm{~km}^{2}\right)$ GGNP $\left(6731 \mathrm{~km}^{2}\right)$, KLNP $\left(5340.13 \mathrm{~km}^{2}\right)$, CRNP $\left(4000 \mathrm{~km}^{2}\right)$, OONP $\left(2512 \mathrm{~km}^{2}\right)$, CBNP $\left(2258 \mathrm{~km}^{2}\right)$, and KNP $\left(1121 \mathrm{~km}^{2}\right)$. These Parks cut across various ecological zones including forest, grassland, savanna and montane forest

A. A. Nchor, Department of Forestry and Wildlife Resources Management, University of Calabar, Calabar, Nigeria.

A. U. Ogogo, Department of Forestry and Wildlife Resources Management, University of Calabar, Calabar, Nigeria. 
ecosystems.

\section{Methods}

The primary data collection tool for the study was the Rapid Appraisal and Prioritization of Protected Area Management (RAPPAM) methodology questionnaire (Ervin 2003c). The questionnaire covers all aspects of the International Evaluation Framework developed by the World Commission on Protected Areas (WCPA) (Hockings, 2003) with emphasis in two major areas:

i. Contextual issues including pressures and future threats, vulnerability, biological and socio - economic importance; ii. Management effectiveness, including a variety of measures under planning, inputs and processes

The questionnaire was administered to 256 respondents: 207 rangers chosen across the seven parks using a proportional representation by applying the " 3 in $K$ " sampling technique where $K=10$, and 49 senior staff ( 7 per park) based on the seven administrative units in each park. Secondary data were obtained from park records.

\section{Data Analysis}

Data obtained were analyzed using descriptive statistics, and Spearman's correlation at $\mathrm{P}<0.05$.

\section{RESULTS AND DISCUSSIONS \\ Pressures and Threats}

Table 1: shows the results of the overall pressures affecting the seven National Parks. Hunting (18.7) was the highest followed by logging and grazing (15.9) each while NTFP's (2.7) was mild.

Table 1: Overall pressures in all the parks

\begin{tabular}{|c|c|c|c|c|c|c|c|c|c|}
\hline Pressure & CRNP & GGNP & CBNP & OONP & ONP & KLNP & KNP & Total & $\begin{array}{l}\text { Average } \\
\text { Scores }\end{array}$ \\
\hline Hunting & 27 & 8 & 27 & 27 & 12 & 12 & 18 & 131 & 18.7 \\
\hline \multirow[t]{3}{*}{ Logging } & 36 & 12 & 0 & 12 & 12 & 12 & 27 & 111 & 15.9 \\
\hline & 8 & 1 & 2 & 2 & 2 & 2 & 2 & 19 & 2.7 \\
\hline & 4 & 4 & 8 & 4 & 2 & 8 & 2 & 32 & 4.6 \\
\hline NTFP's & 27 & 27 & 0 & 0 & 4 & 36 & 0 & 94 & 13.4 \\
\hline Illegal Farming & 0 & 0 & 0 & 36 & 0 & 8 & 0 & 44 & 6.3 \\
\hline Fishing & 8 & 27 & 18 & 18 & 0 & 36 & 0 & 107 & 15.3 \\
\hline Transborder & 18 & 12 & 12 & 0 & 0 & 2 & 0 & 44 & 6.3 \\
\hline Grazing & 4 & 8 & 18 & 18 & 0 & 27 & 36 & 111 & 15.9 \\
\hline Fires & 1 & 2 & 2 & 4 & 0 & 4 & 18 & 31 & 4.4 \\
\hline Total & 133 & 101 & 87 & 121 & 32 & 147 & 103 & 624 & \\
\hline Mean Scores & 13.3 & 10.1 & 8.7 & 12.1 & 3.2 & 14.7 & 10.3 & 6.2 & \\
\hline
\end{tabular}

Table 2 shows the results of the overall threats in the seven National Parks. The average degree of each threat in the seven Parks ranged from 2.7 to 18.7. Hunting (19.6) was the highest across the Parks followed by grazing (18.1), logging (13.7) and enclave communities (14.7). Fishing (12.3) was also high while threats bothering on illegal farming, mining, and transborder were moderate and NTFP as well as illegal fires were mild 
Table 2: Overall Threats in all the parks

\begin{tabular}{llllllllll}
\hline Threats & CRNP & GGNP & CBNP & OONP & ONP & KLNP & KNP & Total & $\begin{array}{l}\text { Average } \\
\text { Scores }\end{array}$ \\
\hline Hunting & 27 & 8 & 10 & 18 & 12 & 18 & 27 & 137 & 19.6 \\
Logging & 36 & 12 & 0 & 0 & 18 & 18 & 12 & 96 & 13.7 \\
NTFP's & 8 & 1 & 2 & 2 & 2 & 2 & 2 & 19 & 2.7 \\
Illegal Farming & 2 & 8 & 4 & 2 & 2 & 8 & 2 & 28 & 4.0 \\
Enclave & 27 & 18 & 0 & 0 & 4 & 36 & 0 & 103 & 14.7 \\
communities & & & & & & & & & \\
Mining & 0 & 0 & 6 & 27 & 0 & 4 & 0 & 31 & 4.4 \\
Fishing & 8 & 27 & 12 & 12 & 0 & 27 & 0 & 86 & 12.3 \\
Transborder & 12 & 12 & 12 & 0 & 0 & 2 & 0 & 38 & 5.4 \\
Grazing & 2 & 8 & 27 & 18 & 0 & 36 & 36 & 127 & 18.1 \\
Fires & 1 & 2 & 2 & 2 & 0 & 2 & 12 & 21 & 3.0 \\
\hline Total & 123 & 96 & 104 & 81 & 38 & 153 & 91 & 686 & 98 \\
\hline Mean scores & 12.3 & 9.6 & 10.4 & 8.1 & 3.8 & 15.3 & 9.1 & 68.6 & \\
\hline
\end{tabular}

Results in CBNP, KNP and GGNP were however moderate while the levels were mild in ONP. Threat to the conservation of biodiversity was highest in KLNP followed by CRNP and CBNP. GGNP, KNP and OONP had moderate threats while ONP suffered from mild threats. The relationship between threats and pressures showed that pressures were positively and significantly correlated $(r=0.69, p<0.05)$ with threats.

in the Parks

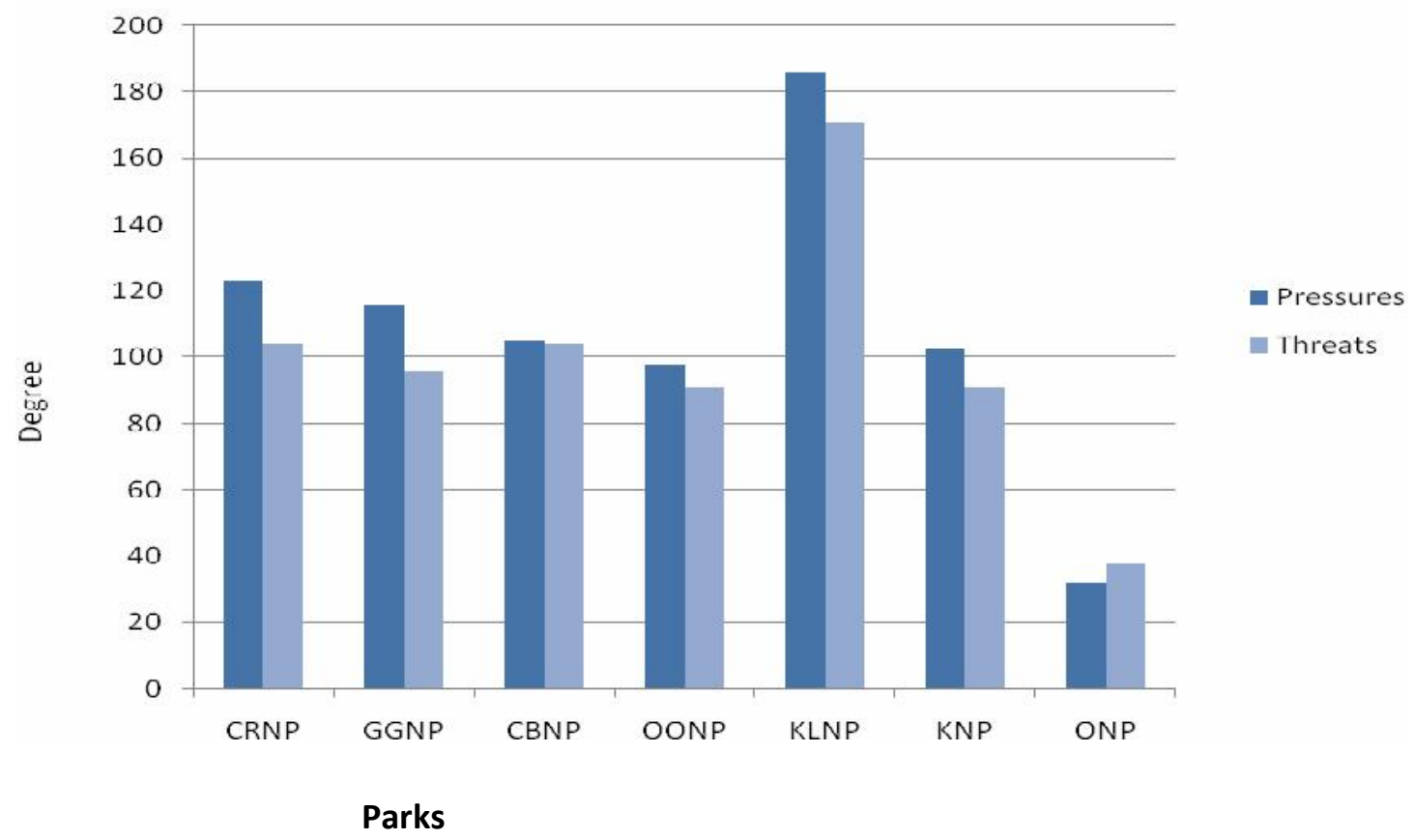

Figure 1: Level of pressures and threats in each Park

Figure 1 shows the level of pressures and threats in each park. Pressures were highest in KLNP followed by CRNP and OONP. 
The Ten most common threats and pressures identified during the study were hunting, logging, enclave communities, grazing, NTRPS, illegal farming, mining, fishing, transborder and wildfires. They were also the most pervasive in all the seven National Parks. Following this, the top four threats and pressures (Hunting, logging, encroachment/Enclave communities and grazing) occurred across the seven parks that were assessed. Such widespread occurrences indicated that threats and pressures in these parks are indeed systematic, reflecting consistent underlying causes rather than the lapses of individual parks.

Poaching of animals and NTFPs are listed as very critical pressures and threats due to their prevalence across the parks. In similar circumstances, poaching has been considered as affecting more than $80 \%$ of 201 parks from 16 tropical countries across three continents (Van Schack et al. 1997). Hunting and NTFP collection occurred in $97 \%$ and $92 \%$ respectively of 197 Russian parks that were accessed (Tyrlyshkin et al. 2003).

Logging operations were severe in CRNP and high in the rest of the parks. Its impacts included loss of habitat, modification of fire regimes, compaction and erosion of soils and development of roads - the precursor to so many accompanying threats.

Logging is completely banned in Nigeria National Parks though many parks across the globe persist in maintaining policies that allow widespread intensive logging in National Parks. Logging affected nearly $70 \%$ of more than 200 parks sampled in the tropics (Van Schack et al. 1997). Most of the parks like CRNP and KNP suffered from severe logging because of its remoteness, high economic value of the species and low level of monitoring by patrol staff.

Encroachment, illegal settlements/ farming were common management problems across the 7 parks. People living in areas that were not compensated or given deeds usually carry out agricultural activities and develop infrastructures which in some cases occurred before National Parks were established. There are always demanding for the enlargement of the areas they occupy inside the Parks.

Grazing and bush burning were rampant across the Parks with high incidences occurring in KNP, KLNP, OONP and CBNP.

Some of the basic origins of pressures and threats in the National Park Service as identified by respondents were as follows:-

- Low level of public awareness in some of the parks.

- High population pressures and prevalent poverty.

- Weak institutional, administrative, planning and management capacity.

- Inadequate data and information on management activities and

- Inadequate policies and strategies for biodiversity conservation.

\section{Vulnerability:}

The data on Table 3 shows the level of vulnerability in the seven parks. The results of the ten vulnerability indicators revealed that six of them received an average score of 3.5 or above indicating a high level of vulnerability in the Parks. The parks are generally vulnerable to biodiversity loss due to difficulties in monitoring illegal activities, civil unrest in the Parks, cultural practices conflicting with park objectives, accessibility to the Parks, high demand for park resources and high value of park resources. When considered together, these six conditions had placed a special emphasis on the likelihood of poaching, logging and NTFPS posing serious threats and increasing in the future. Threats were therefore positively and significantly correlated $(r=0.78, p<0.05)$ with vulnerability. 
Table 3: Vulnerability of all the parks

\begin{tabular}{|c|c|c|c|c|c|c|c|c|c|c|}
\hline \multirow[t]{2}{*}{$\mathrm{S} / \mathrm{NO}$} & \multirow[t]{2}{*}{ INDICATIORS } & \multicolumn{8}{|c|}{ NATIONAL PARKS } & \multirow[b]{2}{*}{ Mean } \\
\hline & & ONP & CRNP & KLNP & OONP & CBNP & GGNP & KNP & Total & \\
\hline 1. & $\begin{array}{l}\text { Difficulties in monitoring illegal } \\
\text { activities within the PA }\end{array}$ & 5 & 5 & 5 & 5 & 5 & 3 & 5 & 33 & 4.7 \\
\hline 2. & Low Law Enforcement in the region & 3 & 3 & 3 & 3 & 3 & 1 & 3 & 19 & 2.7 \\
\hline 3. & $\begin{array}{l}\text { Bribery and Corruption is common } \\
\text { throughout the region }\end{array}$ & 3 & 3 & 3 & 3 & 3 & 3 & 3 & 21 & 3.0 \\
\hline 5. & $\begin{array}{l}\text { PA objectives conflict with cultural } \\
\text { practices, beliefs and traditional } \\
\text { uses }\end{array}$ & 5 & 5 & 5 & 5 & 5 & 5 & 5 & 35 & 5.0 \\
\hline 6. & $\begin{array}{l}\text { Market Value of PA Resources } \\
\text { very high }\end{array}$ & 5 & 5 & 5 & 5 & 5 & 3 & 5 & 33 & 4. 7 \\
\hline 9. & $\begin{array}{l}\text { PA Managers are under Pressure to } \\
\text { unduly Exploit the PA resources }\end{array}$ & 0 & 0 & 0 & 0 & 0 & 0 & 0 & 0 & 0 \\
\hline \multirow[t]{4}{*}{10.} & Recruitment and retention of & 3 & 3 & 3 & 3 & 3 & 3 & 3 & 21 & 3.0 \\
\hline & employment is difficult & & & & & & & & & \\
\hline & Total & 39 & 39 & 39 & 39 & 37 & 27 & 37 & 253 & \\
\hline & Mean & 3.9 & 3.9 & 3.9 & 3.9 & 3.7 & 2.7 & 3.7 & 2.53 & \\
\hline
\end{tabular}




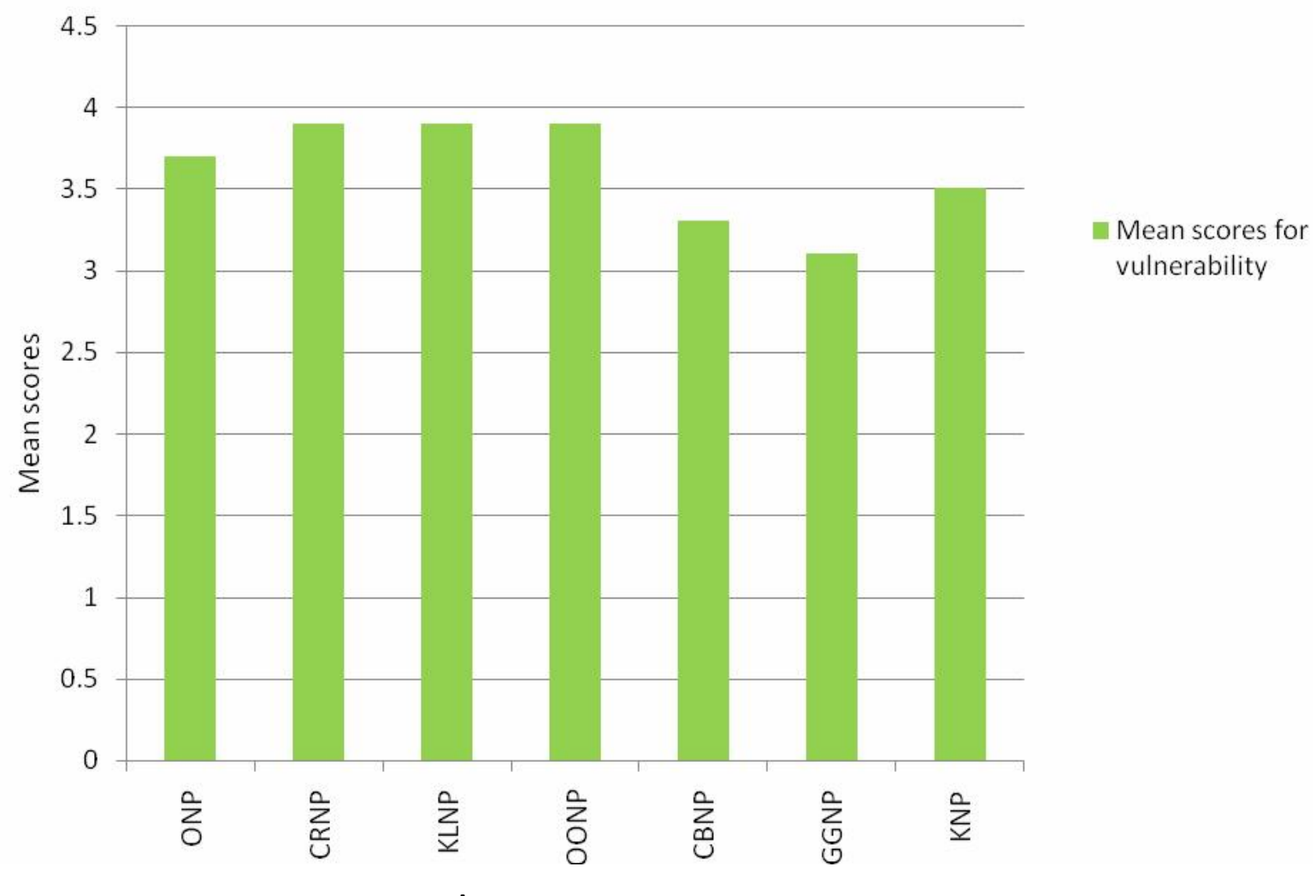

Parks

Figure 2: Level of vulnerability in each park

Figure 2 shows the level of vulnerability in each of the seven parks. The average degree of vulnerability in each of the seven parks indicated that CRNP, OONP, KLNP and ONP were the most vulnerable parks followed by KNP and CBNP. The park with the least level of vulnerability was GGNP.

\section{Legal Security}

Table 4 shows the results of the legal security of the parks. The parks overall average score was 2.9 indicating that the parks were not legally secured. The problems of insecurity of the parks were in the area of inadequate boundary demarcation (2.9), unsettled disputes regarding land tenure or used rights between local communities and park authorities (2.1), inadequate staff and financial resources to conduct critical law enforcement activities (1.6). However, in the area of long term protection the very high scores of (3.5) showed that all the protected areas were legally gazetted or otherwise recognized by the Federal Government of Nigeria and thus not subject to degazettement.
The level of security of individual parks revealed that GGNP (3.8), ONP (3.0), KLNP (3.0) and CBNP (3.0); were adequate, though the scores for CRNP (2.6) and OONP (2.6) as well as KNP (2.0) were inadequate to support effective biodiversity protection in these parks. There was however a significant difference between the level of security in GGNP and the other six parks.

\section{Arrest of Culprits}

Data in table 5 shows the number of persons arrested for various offences between 2001 and 2005 in the seven parks. Out of 3,132 culprits arrested during the period, $50.42 \%$ being the highest was recorded in KNP, while $2.84 \%$ the lowest was recorded in ONP. The levels in OONP, KLNP, CRNP, CBNP and GGNP were $3.8 \%, 20.50 \%, 6.51 \%, 9.36 \%$ and $6.58 \%$ respectively. Grazing (58.2\%) received the highest record of arrest during the period while the lowest record $(0.02 \%)$ was in uncontrolled fires. 
Table 4: Legal security for all parks

\begin{tabular}{|c|c|c|c|c|c|c|c|c|c|c|}
\hline \multirow[b]{2}{*}{ S/NO } & \multirow[b]{2}{*}{ INDICATORS } & \multicolumn{7}{|c|}{ NATIONAL PARKS } & \multicolumn{2}{|c|}{ TOTAL Mean } \\
\hline & & ONP & CRNP & KLNP & OONP & CBNP & GGNP & KNP & & \\
\hline 1 & $\begin{array}{l}\text { The PA has long term legally } \\
\text { binding protection }\end{array}$ & 5 & 5 & 5 & 5 & 5 & 5 & 5 & 7.0 & 35 \\
\hline 2. & $\begin{array}{l}\text { No unsettled disputes regarding } \\
\text { land tenure or used rights }\end{array}$ & 3 & 1 & 1 & 1 & 3 & 5 & 1 & 2.1 & 15 \\
\hline 3. & $\begin{array}{l}\text { Boundary Demarcations is } \\
\text { adequate to meet the PA obj. }\end{array}$ & 3 & 3 & 3 & 3 & 3 & 3 & 3 & 3.0 & 21 \\
\hline 4. & $\begin{array}{l}\text { Adequate staff and financial } \\
\text { resources available to conduct } \\
\text { critical law enforcement activities }\end{array}$ & 1 & 1 & 3 & 1 & 1 & 3 & 1 & 1.6 & 11 \\
\hline 5. & $\begin{array}{l}\text { Conflicts with the local } \\
\text { communities are resolved fairly } \\
\text { and efficiently }\end{array}$ & 3 & 3 & 3 & 3 & 3 & 3 & 0 & 2.6 & 18 \\
\hline & Total & 15 & 13 & 15 & 13 & 15 & 19 & 10 & & 100 \\
\hline & Mean Scores & 3.0 & 2.6 & 3.0 & 2.6 & 3.0 & 3.8 & 2.0 & 2.9 & \\
\hline
\end{tabular}

Table 5: Arrests of culprits for all the parks 2001-2005

\begin{tabular}{|c|c|c|c|c|c|c|c|c|c|}
\hline \multirow[b]{2}{*}{ S/NO. } & \multicolumn{9}{|c|}{ NATIONAL PARKS } \\
\hline & PRESSURE/THREAT & ONP & CRNP & KLNP & OONP & CBNP & GGNP & KNP & Total \\
\hline 1 & Hunting & 57 & 60 & 236 & 57 & 146 & 98 & 103 & 757 \\
\hline 2. & Grazing & & 10 & 262 & & 117 & 3 & 1417 & 1809 \\
\hline 3. & Enclave communities & & 4 & & & & 10 & & 14 \\
\hline 4. & NTFP's & 3 & 35 & & 3 & 2 & 5 & & 48 \\
\hline 5. & $\begin{array}{l}\text { Farming/lllegal } \\
\text { Encroachment }\end{array}$ & 10 & 10 & 37 & 10 & 10 & & 10 & 87 \\
\hline 6. & Fishing & & 5 & 75 & & 10 & 60 & 9 & 159 \\
\hline 7. & Logging & 19 & 70 & 20 & 19 & & 25 & 40 & 193 \\
\hline 8. & Fires & & & & & 2 & & & 2 \\
\hline 9. & Transborder Activities & & 10 & & & 6 & 5 & & 21 \\
\hline 10. & Mining & & & 12 & 30 & & & & 42 \\
\hline & Total & 89 & 204 & 642 & 119 & 293 & 206 & 1579 & 3132 \\
\hline
\end{tabular}

Source: Park records

Staffing: Table 6 shows the staff profile for all the parks as at the end of 2005. Results in the table revealed that 16 $(1.06 \%)$ of the staff were professionals, $33(2.19 \%)$ were technical staff, $1094(72.55 \%)$ were rangers, while administrative staff level stood at $266(17.64 \%)$. 
Table 6: Staff profile of all the parks as at the end of 2005

\begin{tabular}{|c|c|c|c|c|c|c|c|}
\hline \multirow{2}{*}{$\begin{array}{l}\mathrm{S} / \mathrm{N} \\
0\end{array}$} & \multirow[t]{2}{*}{ Park } & \multicolumn{3}{|c|}{ Core Staff } & \multicolumn{2}{|c|}{ Support Staff } & \multirow[b]{2}{*}{ Total } \\
\hline & & $\begin{array}{l}\text { Professional } \\
\mathrm{s}\end{array}$ & Technical & (Rangers etc.) & Admin. Staff & Other Professionals & \\
\hline 1 & ONP & $1(6.25)$ & $2(6.06)$ & $56(5.12)$ & $19(7.14)$ & $8(8.08)$ & 86 \\
\hline 2 & CRNP & $5(31.25)$ & $\begin{array}{l}10 \\
(30.30)\end{array}$ & $221(20.20)$ & $57(21.43)$ & $13(13.13)$ & 306 \\
\hline 3 & KLNP & $3(18.75)$ & $4(12.12)$ & 257 (23.49) & $53(19.92)$ & $30(30.30)$ & 347 \\
\hline 4 & OONP & $3(18.75)$ & $\begin{array}{l}10 \\
(30.30)\end{array}$ & $150(13.71)$ & $60(22.56)$ & $12(12.12)$ & 235 \\
\hline 5 & CBNP & $1(6.25)$ & $2(6.06)$ & $136(12.43)$ & $21(7.89)$ & $5(5.05)$ & 165 \\
\hline 6 & GGNP & $2(12.50)$ & $3(9.09)$ & $195(17.82)$ & $35(13.16)$ & $15(15.15)$ & 250 \\
\hline 7 & KNP & $1(6.25)$ & $2(6.06)$ & $79(7.22)$ & $21(7.89)$ & $16(16.16)$ & 119 \\
\hline & Total & $16(1.06)$ & $33(2.19)$ & $1094(72.55)$ & 266 (17.64) & $99(6.56)$ & 1508 \\
\hline
\end{tabular}

Source: Park records

Figures in Parenthesis are percentages

The major staffing weakness across the seven parks was number of staffs. Lack of funding was the indirect cause of this shortfall. Inadequate staffing is not limited to the Nigeria National Parks alone. Rao et al. (2002), for example, found that $1 \%$ of Myanmar's parks had no staff at all, while $40 \%$ had some staff but not enough to adequately perform management duties. Similarly, Singh (1999) reported that $10 \%$ of India's National Parks and $13 \%$ of its wildlife sanctuaries did not have staff allocated to them. Numerous other studies (e.g. Brandon et al. 1998, Therborgh et al. (2002) corroborate that inadequate staffing is a widespread phenomenon in many protected area systems.

The negative impact of low staffing particularly in the area of protection was wide spread and apparent; preventing staff from carrying out effective law enforcement, regular patrols and habitat management programmes. It was generally agreed by respondents in the seven parks that the staff levels in the parks was inadequate and that staff had no skills to conduct critical research. However, GGNP which is being supported by Nigerian Conservation Foundation (NCF) and the Gashaka Primate Project (GPP) had seemingly overcome this problem through regular involvement of staff in research. The consequences of inadequate trained staff include inadequate communication with local communities and ineffective law enforcement. All the seven Parks expressed their concern over the acute shortage of staff most especially frequently at the Park protection levels. The impacts of low staffing were widespread, ranging from poor to ineffective law enforcement; poor threat detection, litigation, monitoring or prevention; high workloads and staff morale. A range of simple but critical skills such as community relations and conflict resolutions were identified as areas that require improvement.

\section{Funding:}

Table 7 shows the results of allocation of funds for park management programs. Generally, allocation of funds for various park management activities showed that personnel cost including staff salaries gulped (19.6\%), administrative operations (36.9\%) and conservation of park resources (3.4\%) were significantly $(p<0.05)$ different with less emphasis on conservation which is the core responsibilities of the National Park Service. 
Table 7: Allocation of funds for park management programs

\begin{tabular}{llllll}
\hline S/NO. & $\begin{array}{l}\text { NATIONAL } \\
\text { PARKS }\end{array}$ & $\begin{array}{l}\text { PERSONELL } \\
\text { COST }\end{array}$ & PARK CONSERVATION & $\begin{array}{l}\text { ADMIN. } \\
\text { EXPENSES }\end{array}$ & TOTAL \\
\hline & & NM & NM & NM & NM \\
1 & ONP & 80.86 & 1.32 & 28.61 & 114.83 \\
& & $(70.42)$ & $(4.63)$ & $(24.91)$ & $(100.00)$ \\
2 & CRNP & 178.10 & 9.88 & 72.74 & 261.12 \\
3 & KLNP & $(68.36)$ & $(3.78)$ & $(27.86)$ & $(100.00)$ \\
& & 211.08 & 13.80 & $(29.61)$ & 321.14 \\
4 & OONP & $(66.11)$ & $(4.24)$ & 93.37 & $(100.00)$ \\
& & 231.46 & 12.09 & $(27.39)$ & $(100.02$ \\
5 & CBNP & $(69.07)$ & $(3.11)$ & 74.03 & 221.41 \\
& & 140.40 & 6.98 & $(33.44)$ & $(100.00)$ \\
& & $(63.41)$ & $(3.11)$ & 214.92 & 292.60 \\
7 & GGNP & 74.89 & 2.39 & $(73.11)$ & $(100.00)$ \\
& & $(21.63)$ & $(0.82)$ & 31.19 & 110.84 \\
& KNP & 69.49 & 1.76 & $(32.11)$ & $(100.00)$ \\
& & $(62.69)$ & $(1.20)$ & 611.16 & 1666.46 \\
& TOTAL & 994.68 & 16.22 & $(36.94)$ & $(100.00)$ \\
\hline
\end{tabular}

Source: Park records

Figures in Parenthesis are percentages

Inadequate funding was a serious weakness in all the seven Parks during this study. Inadequate funding has led directly to a raft of other management problems, including inadequate field equipment, transportation, and facilities. Underfunding of protected areas appears to be a systemic problem in other parts of the world. James et al. (2001) have documented that protected areas across Africa and Latin America are managed on less than US $\$ 110$ per square kilometer $\left(\mathrm{km}^{2}\right)$, far less than the generally accepted US $\$ 210$ per $\mathrm{km}^{2}$ needed to adequately manage tropical Parks.

\section{CONCLUSION}

The results of the assessment have confirmed that the parks are indeed generally vulnerable to an array of pressures and threats many of them very severe and damaging. However, the hope is that many of the most prevalent and serious pressures and threats could be prevented, mitigated or reversed through sustained national and international cooperation.

Sound resource management lies at the core of the National Park service mandate and should therefore, receive more attention and concern by the management of various Parks. However, this was not evident in this study as the meager allocations of funds to all the Parks was primarily channeled to staff administrative costs with an insignificant portion devoted to protection and conservation of Park resources. To address the most pervasive and widespread threats-encroachment/ enclave communities, logging, fishing, poaching of animals and NTFPs would require a concerted policy effort that would probably result in significant improvement in the overall management of the Parks. The challenge therefore is not in the difficulty of reducing the level of these management problems but in the will to take serious steps in doing so. This can be achieve through increased funding and staffing.

\section{REFERENCES}

Alarape A. O., 2002. Culture and Conservation in Old Oyo National Park, Oyo State, Nigeria. PhD Thesis, University of Ibadan. 280pp.

Brandon K., Redford K. H., Sanderson S. E, eds 1998. Parks in Peril. Washington (D.C). Island Press. 120pp.

Brunner A. G., Gullison R. E., Rice R. E. and da Fonseca G. A. B., 2001. Effectiveness of Parks in protecting tropical biodiversity Science 291: 125 $-128$

Ervin J., 2003a. Protected Area Assessment in Perspective. BioScience 53:819-822

Ervin J., 2003b. Rapid Assessment and Prioritization of Protected Area management (RAPPAM). Gland (Switzerland): World Wide Fund For Nature 52pp.

Heywood V. H., 1995. Global Diversity Assessment Cambridge University Press, Cambridge, UK

Hockings M., Stolton S. and Dudley N., 2000. Evaluating effectiveness, a framework for assessing the management of protected areas. IUCN, Gland, Switzerland. Available at http://wcpa.iucn.org/pubs/pdfs/evaluatingeffectiveness.pdf

Hockings M., 2003. Systems of assessing the effectiveness of management in protected areas. BioScience 53: $823-832$ 
James A, Kanyamibwa S, Green MJB., 2001. Sustainable financing for protected areas in sub-Saharan Africa and the Caribbean. Pages 69-88 in Anderson TL, James A, eds. The Politics and Economics of Park Management. New York: Rowman and Littlefield.

Margoluis R. and Salafsky N., 1999. Threat reduction assessment: a practical and cost effective approach to evaluating conservation and development projects. Conservation Biology 13: $830-841$

Margules C. R. and Pressey R. L., 2000. Systematic Conservation Planning. Nature 405:243-253

Myers N., Mittermeier R. A., Mittermeier C. G., da

Fonseca G. A. B. and Kent J., 2000. Biodiversity hotspots for conservation priorties. Nature 403: $853-858$.

Primm S. L., Russell G. J., Gittleman J. L and Brooks T. M., 1995. The future of biodiversity, Science 259: 347 350

Putz F. E., Blate G. M., Redford K. H., Fimbell R. and Robinson J., 2001. Tropical forest management and conservation of biodiversity: an overview. Conservation Biology 15: $7-20$

Rao M., Rabinowltz A., Khaing S. T., 2000. Status Review of the Protected Area System in Myanmar with Recommendation for Conservation Planning. Conservation Biology 16: $360-368$
Salafsky N., Margoluis R., Redford K. H. and Robinson J. G., 2002. Improving the practice of conservation. A conceptual framework and research agenda for conservation science. Conservation Biology. 16: $1469-1479$

Singh S., 1999. Assessing Management Effectiveness of Wildlife Protected Areas in India. Parks 9 (2): 34-49

Terborgh J., Van Schalk C., Davenport I., Roa M., eds., 2002. Making Parks Work: Strategies for Preserving Tropical Nature. Washington (DC): Island Press

Tyrlyshkin V., Blagovidod A., Belokurov A., 2003. Russia Case Study - Management Effectiveness Assessment of Protected Areas using WWF's RAPPAM Methodology. Gland (Switzerland). World Wide Fund for Nature

Van Schalk C., Terborgh J., Dugellby B., 1997. The Silent Crises. The state of rain forest nature reserves. Pages $64-89$ in Kramer R, Van Schalk C.P, Johnson J, eds. The Last Stand. Protected Areas and the Defense of Tropical Bio - diversity. New York: Oxford University Press.

Whitemore D. S., 1997. Tropical forest disturbance, disappearance and species loss. In: Laurence W. L. and Bieregaard R. O. Jr. (eds), Tropical Forest Remnants: Ecology, Management, and Conservation of Fragmented Communities. University of Chicago Press, Chicago, pp 3-12. 